\title{
Triazoloisoquinoline-Based/Ruthenium-Hybrid Sensitizer for Efficient Dye-Sensitized Solar Cells
}

\author{
Che-Lung Lee, ${ }^{1}$ Wen-Hsi Lee, ${ }^{1}$ and Cheng-Hsien Yang ${ }^{2}$ \\ ${ }^{1}$ Department of Electrical Engineering, Nation Cheng Kung University, No. 1, Daxue Road, East District, Tainan City 70101, Taiwan \\ ${ }^{2}$ ShiFeng Technology Co., Ltd., Room 603, Building. R2, No. 31, Gongye 2nd Road, Annan District, Tainan 70955, Taiwan \\ Correspondence should be addressed to Cheng-Hsien Yang; jasonyang@fusol-material.com
}

Received 8 September 2013; Accepted 12 October 2013

Academic Editor: Teen-Hang Meen

Copyright (c) 2013 Che-Lung Lee et al. This is an open access article distributed under the Creative Commons Attribution License, which permits unrestricted use, distribution, and reproduction in any medium, provided the original work is properly cited.

\begin{abstract}
Triazoloisoquinoline-based organic dyestuffs were synthesized and used in the fabrication of dye-sensitized solar cells (DSSCs). After cosensitization with ruthenium complex, the triazoloisoquinoline-based organic dyestuffs overcame the deficiency of ruthenium dyestuff absorption in the blue part of the visible spectrum. This method also fills the blanks of ruthenium dyestuff sensitized $\mathrm{TiO}_{2}$ film and forms a compact insulating molecular layer due to the nature of small molecular organic dyestuffs. The incident photon-to-electron conversion efficiency of N719 at shorter wavelength regions is $49 \%$. After addition of a triazoloisoquinoline-based dyestuff for co-sensitization, the IPCE at 350-500 nm increased significantly. This can be attributed to the increased photocurrent of the cells, which improves the dye-sensitized photoelectric conversion efficiency from $6.23 \%$ to $7.84 \%$, and the overall conversion efficiency increased by about $26 \%$. As a consequence, this low molecular weight organic dyestuff is a promising candidate as coadsorbent and cosensitizer for highly efficient dye-sensitized solar cells.
\end{abstract}

\section{Introduction}

To date, there are two kinds of dyestuff used in DSSCs, one is based on metal-free organic materials and the other on ruthenium metal complexes [1-3]. In 1993, Nazeeruddin et al. successfully used the ruthenium complex-cis-bis (isothiocyanato)bis (2,2' -bipyridyl-4,4' -dicarboxylato)-ruthenium(II) (N3) as a sensitizer, with the photoelectric conversion efficiency, $\eta$, reaching about $10 \%$ [4]. However, in view of their lower cost and greater diversity of molecular structures, organic dyestuffs are now attracting more attention than ruthenium complexes.

Although many studies focus on ruthenium complexes for the dyeing of $\mathrm{TiO}_{2}$ photoelectrodes, the related molar absorption coefficient is lower than that for the metal-free organic dyestuffs [5-7]. In order to combine the advantages of ruthenium complexes (i.e., high photoelectric conversion efficiency) and metal-free organic dyestuffs (i.e., high molar absorption coefficient), many studies examine cosensitized DSSCs [8-10]. For example, Miao et al. obtained a high efficiency of $11.05 \%$ by using (tri(isothiocyanato) $\left(2,2^{\prime}: 6^{\prime}, 2^{\prime \prime}\right.$-terpyridyl- $4,4^{\prime}, 4^{\prime \prime}$ tricarboxylic acid)ruthenium(II)) (BD) to overcome the deficient areas in the NIR absorption spectra of cis-dithiocyanate- $\mathrm{N}, \mathrm{N}^{\prime}$-bis-(4-carboxylate-4-tetrabutyl ammoniumcarboxylate-2,2' -bipyridine)ruthenium(II) (N719) [8]. However, to the best of our knowledge, few studies examine the use of cosensitization to broaden the light absorption spectra of N719 in the blue part of the visible spectrum. In this work, we report a new triazoloisoquinoline-based dyestuff, which can be used in a cosensitized dyestuff to absorb the blue part of the visible spectrum. By combining the triazoloisoquinolinebased dyestuff and the N719 sensitizer, greater efficiency is obtained than seen with the individual dye cells.

\section{Experimental Procedure}

2.1. Fabrication of Photovoltaic Devices. Twelve-micrometer nanocrystalline $\mathrm{TiO}_{2}$ photoelectrodes were prepared from a titania paste (Ti-Nanoxide T series, Solaronix SA). The paste was applied to a transparent conducting oxide by doctor-blading techniques and annealed at $450^{\circ} \mathrm{C}$ for $30 \mathrm{~min}$ 
in air. The thickness of the $\mathrm{TiO}_{2}$ films was measured with an Alpha-Step 300 profiler. When the $\mathrm{TiO}_{2}$ electrodes cooled down to around $100^{\circ} \mathrm{C}$, the electrodes were dipped in dye solutions, which included $0.5 \mathrm{mM}$ N719 and different concentrations of dyestuff $4 \mathrm{~L}$ in tert-butanol/acetonitrile (AN) (1:1 in volume). The $\mathrm{TiO}_{2}$ electrodes were immersed in the dye solutions, then kept at $25^{\circ} \mathrm{C}$ for more than $18 \mathrm{~h}$ to allow the dye to adsorb to the $\mathrm{TiO}_{2}$ surface, and rinsed with the same solvents. The dye-loaded $\mathrm{TiO}_{2}$ film as the working electrode and Pt-coated TCO as the counter electrode were separated by a hot-melt Surlyn sheet $(25 \mu \mathrm{m})$ and sealed together by pressing them under heat. The electrolytes were introduced into the gap between the working and the counter electrodes from two holes predrilled on the back of the counter electrode. Finally, the two holes were sealed with a Surlyn film covering a thin glass slide under heat. The cells were evaluated by using 0.6 M [BMI][I], 0.1 M GuNCS, $0.3 \mathrm{M} \mathrm{I}_{2}$, and $0.5 \mathrm{M} \mathrm{TBP}$ in an MPN (3-Methoxypropionitrile) solvent as the redox electrolyte.

2.2. Photovoltaic Measurement. Absorption spectra were recorded on a Agilent 8453 spectrophotometer. The current density-voltage $(J-V)$ characteristics in the dark and under illumination were measured with a Keithley 2400 sourcemeter. The photocurrent was measured in a nitrogen-filled glove box under a solar simulator (Oriel $96000150 \mathrm{~W}$ ) with AM 1.5G-filtered illumination $\left(100 \mathrm{~mW} \mathrm{~cm}^{-2}\right)$. The spectramismatch factor of the simulated solar irradiation was corrected using a Schott visible-color glass-filtered (KG5 color filter) Si diode (Hamamatsu S1133). The active area of the device was $0.25 \mathrm{~cm}^{2}$.

\section{Results and Discussion}

Metal-free organic dyestuffs have been extensively studied in DSSCs, but few reports discuss triazoloisoquinolinebased ones. Triazoloisoquinoline contains electron-rich nitrogen and oxygen heteroatoms in a heterocyclic structure with high electron-donating ability, and it is a good candidate for metal-free organic dyestuffs for use in DSSCs. This study is the first report of the use of triazoloisoquinoline dyestuffs as a cosensitizer to absorb the blue part of the visible spectrum. The synthesis of organic dyestuff $4 \mathrm{~L}$ is depicted in Figure 1. They consist of treating triazoloisoquinolines substituted tetramethyl-dioxaborolane (2) with 5-formyl-2-bromothiophene under conditions for Suzuki coupling to produce 5-(4-(3-oxo- $[1,2,4]$ triazolo[3,4a]isoquinolin-2(3H)-yl)phenyl)thiophene-2-carbaldehyde (3). Knoevenagel condensation of compound 3 with cyanoacrylic acid is carried out in the presence of piperidine, and after precipitation and purification with silica gel chromatography, the final dyestuff $4 \mathrm{~L}$ is obtained as a yellow powder. This product has been characterized by spectroscopic analyses ( ${ }^{1} \mathrm{H}$ NMR $\left(300 \mathrm{MHz}, \mathrm{d}_{6}\right.$-DMSO): $\delta 8.32(\mathrm{~d}, 1 \mathrm{H}, J=7.50 \mathrm{~Hz}), 8.23(\mathrm{~s}, 1 \mathrm{H}), 8.20(\mathrm{~d}, 2 \mathrm{H}$, $J=3.20 \mathrm{~Hz}), 7.93(\mathrm{~d}, 2 \mathrm{H}, J=8.72 \mathrm{~Hz}), 7.89 \sim 7.67(\mathrm{~m}$, $6 \mathrm{H}), 7.03(\mathrm{~d}, 1 \mathrm{H}, J=7.46 \mathrm{~Hz})$; ESI-MS $m / z 437\left(\mathrm{M}-\mathrm{H}^{+}\right)$; Anal. Calcd for $\mathrm{C}_{24} \mathrm{H}_{14} \mathrm{~N}_{4} \mathrm{O}_{3} \mathrm{~S}$ : C, 65.74; $\mathrm{H}, 3.22 ; \mathrm{N}, 12.78$.
TABLE 1: Photovoltaic parameters of the DSSCs with N719:4L sensitizers in different molar ratios under AM 1.5G sunlight ${ }^{\mathrm{a}}$.

\begin{tabular}{lccccc}
\hline & $\begin{array}{c}\text { Dyestuffs } \\
\text { molar } \\
\text { ratio }\end{array}$ & $\begin{array}{c}J_{\mathrm{sc}} \\
\left(\mathrm{mA} \mathrm{cm}^{-2}\right)\end{array}$ & $\begin{array}{c}V_{\mathrm{oc}} \\
(\mathrm{V})\end{array}$ & FF & $\eta(\%)$ \\
\hline Device A & $4 \mathrm{~L}$ & 7.14 & 0.71 & 0.64 & 3.21 \\
Device B & $\mathrm{N} 719$ & 12.55 & 0.78 & 0.64 & 6.23 \\
Device C & $\begin{array}{c}\mathrm{N} 719-4 \mathrm{~L} \\
1: 0.05\end{array}$ & 12.71 & 0.76 & 0.66 & 6.37 \\
Device D & $\begin{array}{c}\mathrm{N} 719-4 \mathrm{~L} \\
1: 0.15\end{array}$ & 14.63 & 0.78 & 0.65 & 7.38 \\
Device E & $\begin{array}{c}\mathrm{N} 719-4 \mathrm{~L} \\
1: 0.25\end{array}$ & 15.29 & 0.78 & 0.66 & 7.84 \\
Device F & $\begin{array}{c}\mathrm{N} 719-4 \mathrm{~L} \\
1: 0.35\end{array}$ & 15.11 & 0.74 & 0.66 & 7.35 \\
\hline
\end{tabular}

${ }^{\mathrm{a}}$ Performances of the DSSCs were measured with a $0.25 \mathrm{~cm}^{2}$ working area.

\% Found: C, $65.96 ; \mathrm{H}, 3.28 ; \mathrm{N}, 12.60 ; \lambda \max / \mathrm{nm}\left(\varepsilon / \mathrm{M}^{-1} \mathrm{~cm}^{-1}\right)$ : 277 (19435), 380 (29651)).

The absorption spectra of the dyestuffs $4 \mathrm{~L}$ and N719 in DMF (Dimethylformamide) solutions are shown in Figure 2. The absorption spectrum of $4 \mathrm{~L}$ shows two major bands at ca. 250-350 $\mathrm{nm}$ and ca. 350-500 $\mathrm{nm}$. UV absorption is attributed to localized aromatic $\pi-\pi^{*}$ transitions. In the visible region, this may be attributed to intramolecular charge transfer (ICT) absorption, because an efficient charge-separated excited state could be produced between the triazoloisoquinoline and the cyanoacrylic acid moieties. The ICT absorption $(\lambda \max )$ appeared at $380 \mathrm{~nm}$ for $4 \mathrm{~L}$, and the molar extinction coefficients in the visible region were $29651 \mathrm{M}^{-1} \mathrm{~cm}^{-1}$. The molar extinction coefficient is twice as high as that of the ruthenium complexes. Interestingly, the maximum absorption peaks and absorption bands of dyestuffs were red-shifted compared to their spectra in DMF solution, which can be ascribed to the electronic coupling of the dyes on the $\mathrm{TiO}_{2}$ surface. The interaction between the $\mathrm{COOH}$ group and the surface $\mathrm{Ti}^{4+}$ ions can lead to the increased delocalization of the $\pi^{*}$ orbital of the conjugated framework, and thus, the energy of the $\pi^{*}$ level was decreased by this delocalization, resulting in the red-shifted absorption spectra. However, 4L shows a good potential to broaden the light absorption spectra of N719 in the blue part of the visible spectrum.

The photovoltaic characteristics of these dyes with regard to their use as sensitizers for DSSCs have been evaluated with a sandwich DSSC cell using 0.6 M [BMI][I], 0.1 M GuNCS, $0.3 \mathrm{M} \mathrm{I}_{2}$, and $0.5 \mathrm{M} \mathrm{TBP}$ in an MPN solvent as the redox electrolyte. Details of the preparation and characterization of the device are described in the experimental section of this work in the supporting information, and all the essential properties of these cells are listed in Figure 3 and Table 1. Under the standard AM 1.5G irradiation, the maximum efficiency $(\eta)$ for the N719-sensitized solar cell-device B with an active area of $0.25 \mathrm{~cm}^{2}$ was calculated to be $6.23 \%$, with a $J_{\mathrm{sc}}$ of $12.55 \mathrm{~mA} \mathrm{~cm}^{-2}$, a $V_{\text {oc }}$ of $0.78 \mathrm{~V}$, and a fill factor (FF) of 0.64. However, device A, based on dyestuff $4 \mathrm{~L}$, 
<smiles>O=c1n(-c2ccc(Br)cc2)nc2c3ccccc3ccn12</smiles>

1

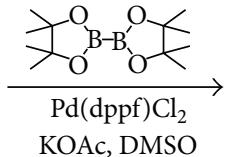

KOAc, DMSO<smiles>CC1(C)OB(c2ccc(-n3nc4c5ccccc5ccn4c3=O)cc2)OC1(C)C</smiles><smiles>O=Cc1ccc(Br)s1</smiles><smiles>CCCC(C(C)Cl)C(C)C(C)(C)C</smiles>

$4 \mathrm{~L}$<smiles>O=Cc1ccc(-c2ccc(-n3nc4c5ccccc5ccn4c3=O)cc2)s1</smiles>

3

FIGURE 1: Synthesis of organic dyestuff 4L.

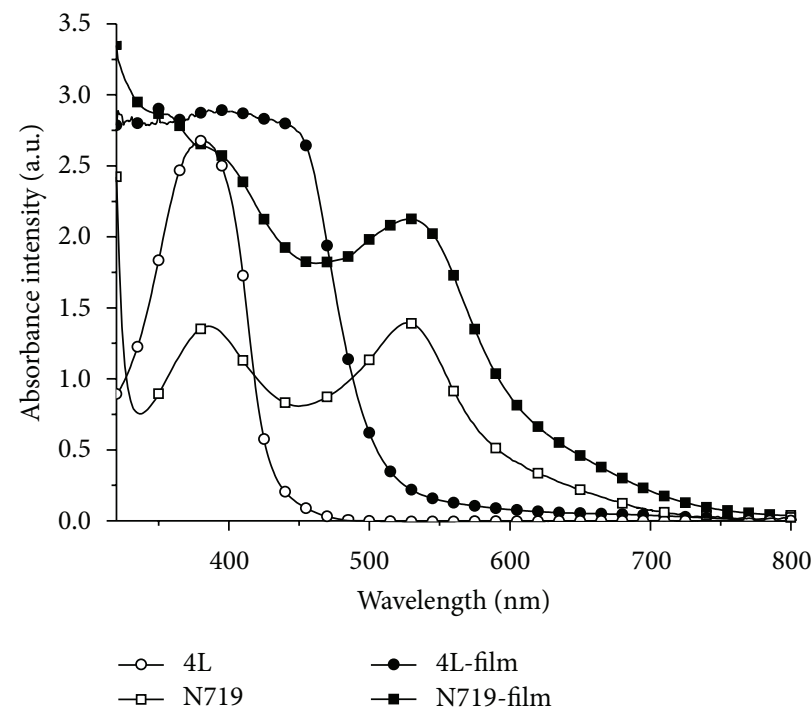

FIGURE 2: Absorption spectra of dyestuffs in DMF and spectra of dyestuffs adsorbed on $\mathrm{TiO}_{2}$ film.

showed relatively low $J_{\text {sc }}-7.14 \mathrm{~mA} \mathrm{~cm}^{-2}, V_{\text {oc }}-0.71 \mathrm{~V}$, and FF0.64 , leading to a lower $\eta$ value of $3.21 \%$. This is reasonable, as dyestuff $4 \mathrm{~L}$ has narrower absorption in the blue part of the visible region (as shown in Figures 2 and 4), and hence could not capture enough solar radiation energy in comparison with N719. In addition, the large $\pi$-conjugated system of triazoloisoquinoline causes stronger intermolecular $\pi-\pi$ interaction, leading to unfavorable $\pi$-stacked dye aggregation on $\mathrm{TiO}_{2}$ in the single sensitizer dyeing device A. Generally, close $\pi$-stacked dye aggregation leads to inefficient electron injection, resulting in a low $\eta$ value due to the formation of excited triplet states [11]. Based on these physical properties, dyestuff $4 \mathrm{~L}$ was used as cosensitizer to overcome the deficiency of N719 absorption in the 350-500 nm range.
Cosensitized solar cells based on the $12 \mu \mathrm{m}$ transparent layer yielded a remarkably high photocurrent density of 12.71 , 14.63, and 15.29. The best cosensitized solar cell, which was sensitized by N719-4L with a 1 to 0.25 molar ratio, showed an open circuit voltage of $0.78 \mathrm{~V}$ and a fill factor of 0.66 , corresponding to an overall power conversion efficiency of $7.84 \%$. This result is also in agreement with the observation of the incident photon-to-electron conversion efficiency (IPCE) action spectra of the DSSCs presented in Figure 4. On the other hand, device A, sensitized with dyestuff $4 \mathrm{~L}$, exhibited a lower $V_{\text {oc }}-0.71 \mathrm{~V}$, while devices C, D, and E cosensitized with dyestuffs $4 \mathrm{~L}$ and N719 showed only small changes in the $V_{\mathrm{oc}}$ value. These values are very close to that of device $\mathrm{B}$, based on N719, which is $0.78 \mathrm{~V}$. This result is attributed to 


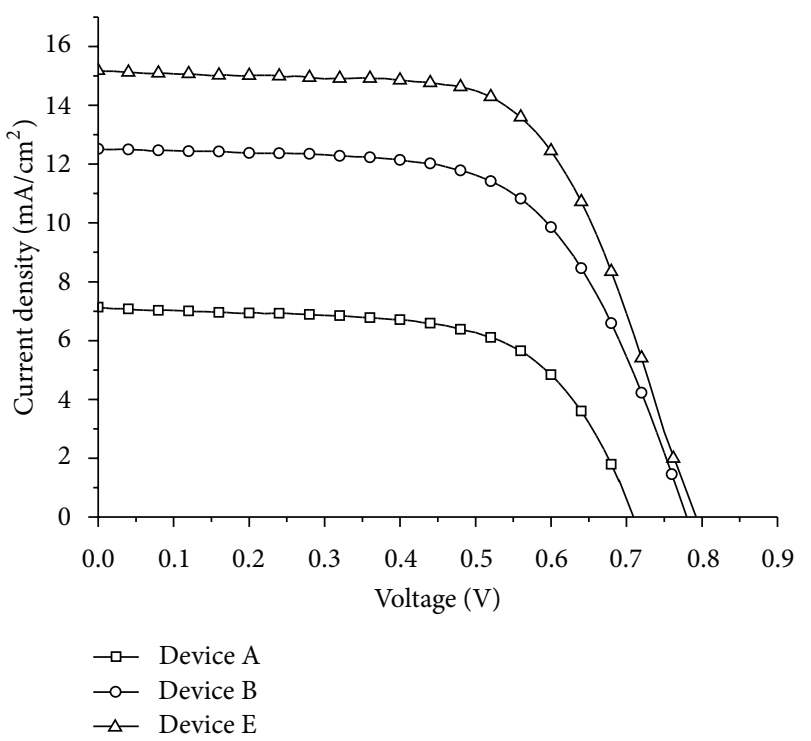

Figure 3: $J-V$ curves of solar cells sensitized by 4L (device A), N719 (device B), and N719:4L (1:0.25) (device E) with $12.0 \mu \mathrm{m}$ single layer nanocrystalline $\mathrm{TiO}_{2}$ electrodes.

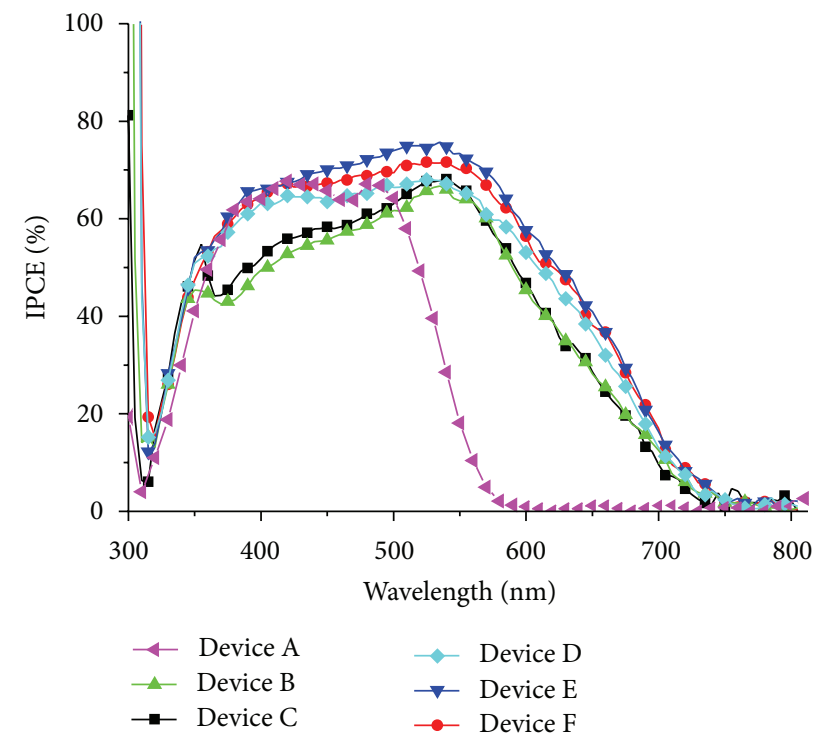

FIGURE 4: IPCE action spectra of solar cells sensitized by $4 \mathrm{~L}$ (device A), N719 (device B), N719: 4L (1:0.05) (device C), N719: 4L (1:0.15) (device D), N719:4L (1:0.25) (device E), and N719:4L (1:0.35) (device F) with $12.0 \mu \mathrm{m}$ single layer nanocrystalline $\mathrm{TiO}_{2}$ electrodes.

the coadsorbent effect of dyestuff $4 \mathrm{~L}$, which has been applied successfully to prepare an insulating molecular layer with N719 [12, 13].

IPCE as a function of wavelength was measured to evaluate the photoresponse of the photoelectrodes in the whole spectra region. As shown in Figure 4, the maximum IPCE of the dyestuff $4 \mathrm{~L}$ based device A was ca. $67 \%$ at $420 \mathrm{~nm}$. This indicates that dyestuff $4 \mathrm{~L}$ has good light harvesting effects at shorter wavelength regions. Device B exhibited the maximum IPCE of $c a .66 \%$ at $550 \mathrm{~nm}$ for the N719 sensitized solar cell. The incident photon-to-electron conversion efficiency of N719 at shorter wavelength regions ( $c a .52 \%$ at $420 \mathrm{~nm}$ ) is thus not as good as at longer ones [14]. This is a niche for organic dyestuffs, such as dyestuff $4 \mathrm{~L}$, which can enhance absorption at shorter wavelength regions. When dyestuff $4 \mathrm{~L}$ was added to the dye solution, the IPCE of devices D and $\mathrm{E}$ at $350-500 \mathrm{~nm}$ increased significantly. The maximum IPCE increased from $52 \%$ to $64 \%$ when 0.15 molar ratio dyestuff $4 \mathrm{~L}$ was added to the dye solution. After increasing the concentration of $4 \mathrm{~L}$ to a 0.25 molar ratio, the maximum IPCE increased from $52 \%$ to $67 \%$. Upon dyestuff $4 \mathrm{~L}$ coadsorption, the maximum IPCE improved significantly, compared to that seen with device $B$, which can be attributed to the increased photocurrent of the DSSCs. Cosensitization broadens the photocurrent action spectrum covering the visible domain at $350-500 \mathrm{~nm}$. The related experimental data are in line with the results in Table 1 and Figure 3.

It is well known that organic dyestuffs will compete with N719 for adsorption on the $\mathrm{TiO}_{2}$ surface. As shown in Figure 4 and Table 1 for devices C, D, and E, there is a balanced relationship between dyestuff $4 \mathrm{~L}$ and N719 cosensitizers. The IPCE spectra of device $C$ have a similar response to those of device $\mathrm{B}$, which indicates that the concentration of $4 \mathrm{~L}$ (a 0.05 molar ratio) was not enough to anchor the blank of the insulating molecular layer. This caused the performance of device $\mathrm{C}$ to rise slightly and produced $\eta=6.37 \%, J_{\mathrm{sc}}=12.71 \mathrm{~mA} \mathrm{~cm}^{-2}, V_{\mathrm{oc}}=0.76 \mathrm{~V}$, and $\mathrm{FF}=0.66$. Obviously, when the concentration of $4 \mathrm{~L}$ was increased to a 0.15 and 0.25 molar ratio, this led to greater efficiency, which is attributed to the significant enhancement of $J_{s c}$, mainly due to the perfect insulating molecular layer and good incident photo-to-electron conversion efficiency at shorter wavelengths. Because of this layer, the best cell performance was achieved, with $\eta=7.84 \%, J_{\mathrm{sc}}=15.29 \mathrm{~mA} \mathrm{~cm}^{-2}$, $V_{\mathrm{oc}}=0.78 \mathrm{~V}$, and $\mathrm{FF}=0.66$. When the concentration of $4 \mathrm{~L}$ was increased to a 0.35 molar ratio, the performance of 
the device began to deteriorate and produced $\eta=7.35 \%$, $J_{\mathrm{sc}}=15.11 \mathrm{~mA} \mathrm{~cm}^{-2}, V_{\mathrm{oc}}=0.74 \mathrm{~V}$, and FF $=0.66$. These results indicate that cosensitization with $4 \mathrm{~L}$ in a 0.25 molar ratio is very effective in improving solar cell performance.

\section{Conclusions}

This study investigated the role of triazoloisoquinoline dyestuffs as a cosensitizer with N719. The results show that coadsorption of N719 sensitizer with dyestuff 4L onto nanocrystalline $\mathrm{TiO}_{2}$ films significantly increased the photocurrent in a 1 to 0.25 molar ratio, thus enhancing the total conversion efficiency. The cell produced in this work achieved an energy conversion efficiency as high as 7.84\% at $100 \mathrm{~mW} \mathrm{~cm}^{-2}$ and AM 1.5G. This improved conversion efficiency is attributed to the insulating molecular layer, which was composed of the small molecular organic dyestuff $4 \mathrm{~L}$ and N719, and the better light harvesting effect at shorterwavelength regions. It is anticipated that the findings of this work will contribute to the development of a cosensitizer which absorbs at shorter-wavelength regions in DSSCs.

\section{References}

[1] B. O. 'Regan and M. Gratzel, "A low-cost, high-efficiency solar cell based on dye-sensitized colloidal $\mathrm{TiO}_{2}$ films," Nature, vol. 353, pp. 737-740, 1991.

[2] A. Mishra, M. K. R. Fischer, and P. Bauerle, "Metal-free organic dyes for dye-sensitized solar cells: from structure: property relationships to design rules," Angewandte Chemie, vol. 48, no. 14, pp. 2474-2499, 2009.

[3] A. Hagfeldt, G. Boschloo, L. Sun, L. Kloo, and H. Pettersson, "Dye-sensitized solar cells," Chemical Reviews, vol. 110, no. 11, pp. 6595-6663, 2010.

[4] M. K. Nazeeruddin, A. Kay, L. Rodicio et al., "Conversion of light to electricity by cis-X2bis(2,2'-bipyridyl-4,4'dicarboxylate)ruthenium(II) charge-transfer sensitizers (X = $\mathrm{Cl}-, \mathrm{Br}-, \mathrm{I}-, \mathrm{CN}-$, and SCN-) on nanocrystalline titanium dioxide electrodes," Journal of the American Chemical Society, vol. 115, p. 6382, 1993.

[5] J. He, W. Wu, J. Hua et al., "Bithiazole-bridged dyes for dyesensitized solar cells with high open circuit voltage performance," Journal of Materials Chemistry, vol. 21, pp. 6054-6062, 2011.

[6] Y. Numata, I. Ashraful, Y. Shirai, and L. Han, "Preparation of donor-acceptor type organic dyes bearing various electronwithdrawing groups for dye-sensitized solar cell application," Chemical Communications, vol. 47, no. 21, pp. 6159-6161, 2011.

[7] L.-Y. Lin, C.-H. Tsai, K.-T. Wong et al., "Organic dyes containing coplanar diphenyl-substituted dithienosilole core for efficient dye-sensitized solar cells," The Journal of Organic Chemistry, vol. 75, no. 14, pp. 4778-4785, 2010.

[8] Q. Miao, L. Wu, J. Cui, M. Huang, and T. Ma, "A new type of dyesensitized solar cell with a multilayered photoanode prepared by a film-transfer technique," Advanced Materials, vol. 23, no. 24, pp. 2764-2768, 2011.

[9] J. H. Yum, S. R. Jang, P. Walter et al., "Efficient co-sensitization of nanocrystalline $\mathrm{TiO}_{2}$ films by organic sensitizers," Chemical Communications, no. 44, pp. 4680-4682, 2007.
[10] Y. Hong, J. Liao, D. Cao et al., "Organic dye bearing asymmetric double donor- $\pi$-acceptor chains for dye-sensitized solar cells," The Journal Organic Chemistry, vol. 76, p. 8015, 2011.

[11] B. Liu, W. Zhu, Q. Zhang et al., "Conveniently synthesized isophorone dyes for high efficiency dye-sensitized solar cells: tuning photovoltaic performance by structural modification of donor group in donor- $\pi$-acceptor system ," Chemical Communications, no. 13, pp. 1766-1668, 2009.

[12] S. Rühle, M. Greenshtein, S.-G. Chen et al., "Molecular adjustment of the electronic properties of nanoporous electrodes in dye-sensitized solar cells," Journal of Physical Chemistry B, vol. 109, no. 40, pp. 18907-18913, 2005.

[13] J. H. Yum, P. Walter, S. Huber et al., "Efficient far red sensitization of nanocrystalline $\mathrm{TiO}_{2}$ films by an unsymmetrical squaraine dye," Journal of the American Chemical Society, vol. 129, pp. 10320-10321, 2007.

[14] A. Mishra, N. Pootrakulchote, M. K. R. Fischer et al., "Design and synthesis of a novel anchoring ligand for highly efficient thin film dye-sensitized solar cells," Chemical Communications, no. 46, pp. 7146-7148, 2009. 

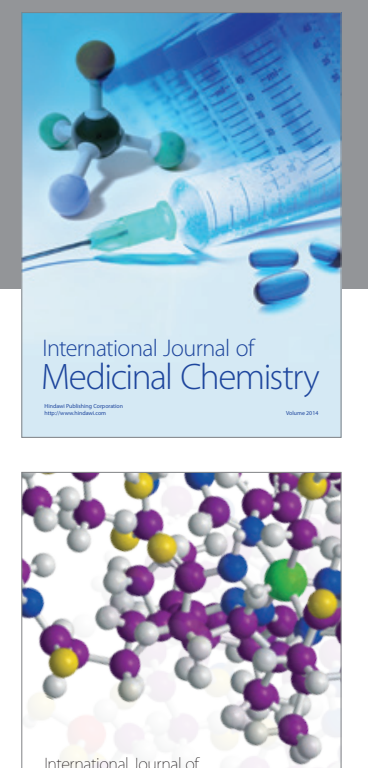

\section{Carbohydrate} Chemistry

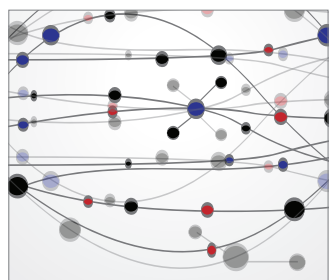

The Scientific World Journal
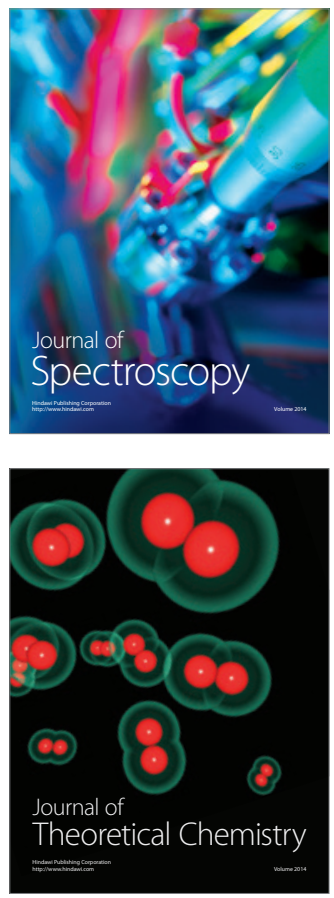
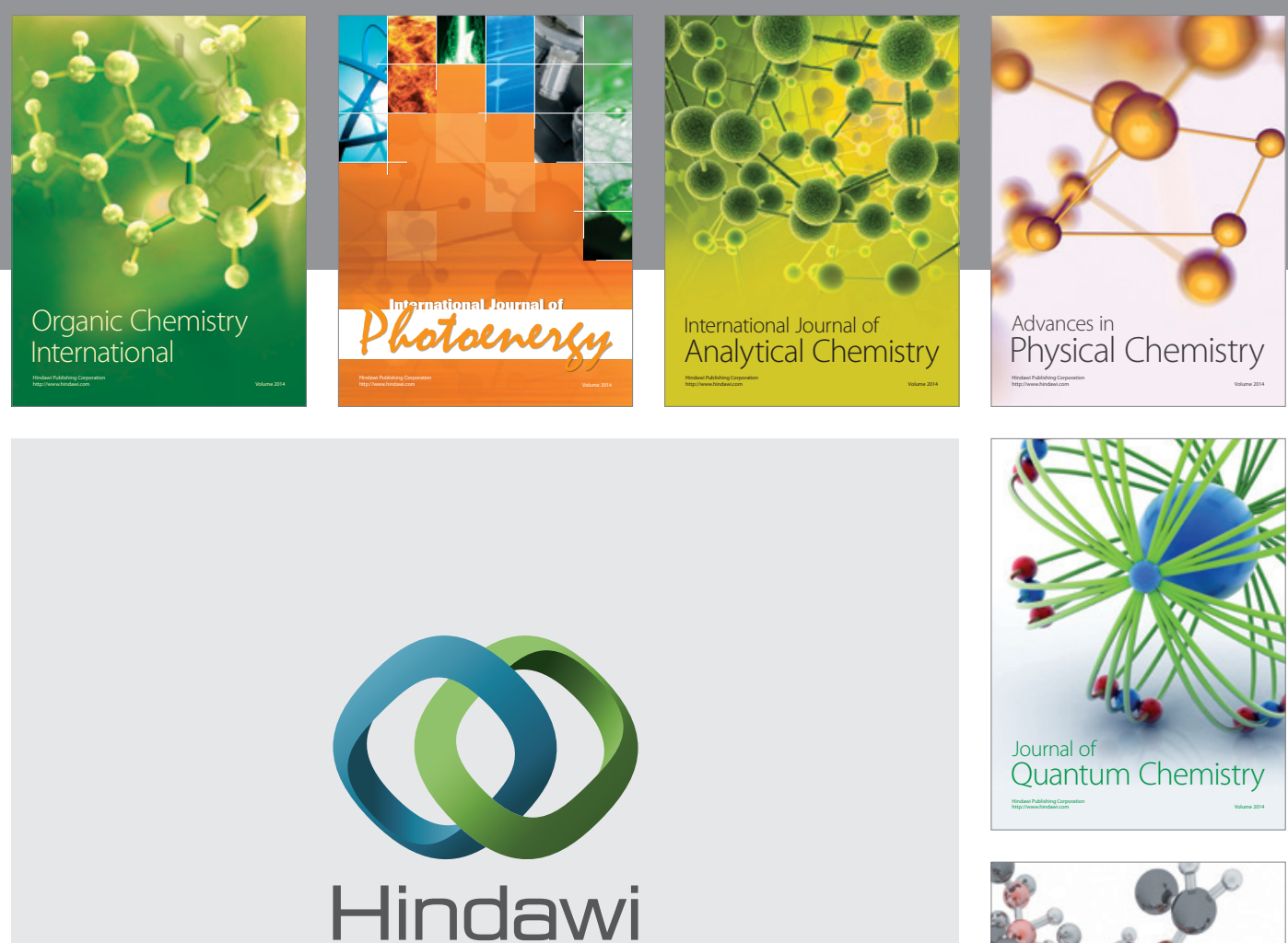

Submit your manuscripts at

http://www.hindawi.com

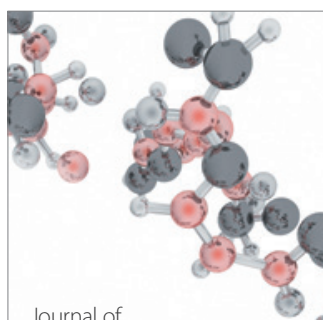

Analytical Methods

in Chemistry

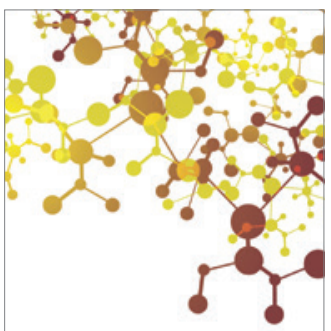

Journal of

Applied Chemistry

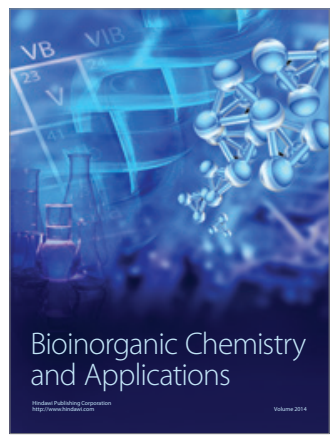

Inorganic Chemistry
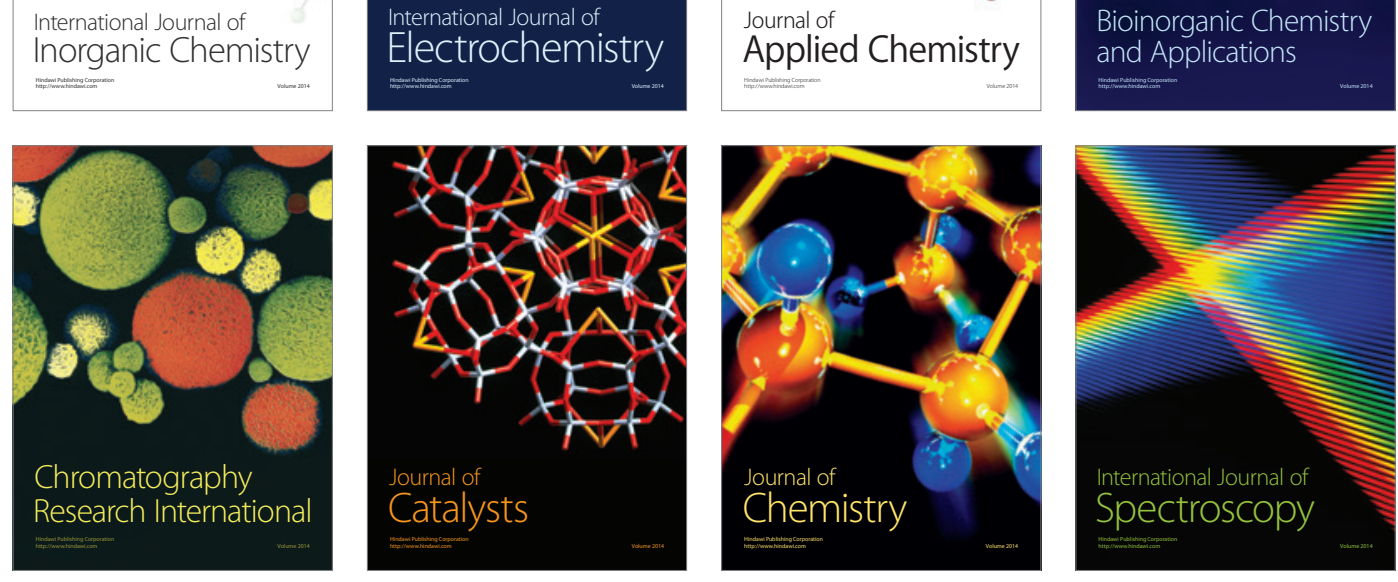